\title{
A characteristic of mycelium biomass of edible boletus
}

\author{
WANDA WOŹNIAK \\ Department of Fruit and Vegetable Technology, Institute of Food Technology \\ The August Cieszkowski Agricultural University of Poznań \\ Wojska Polskiego 31, PL-60-624 Poznań,wozwa@owl.au.poznan.pl
}

Woźn ia k W.:Acharacteristic ofmyceliumbiomass ofedibleboletus. Acta Mycol.42(1):129-140, 2007.

The paper presents the results of studies on the production and quality assessment of mycelia of three varieties of King Bolete: Boletus edulis var. pinicolus Vitt. Boletus edulis var. piceicolus Vasilkov and Boletus edulis var. reticulatus (Schaeff. ex Boud.) Bat. In the biomass of mycelium for food the following physicochemical parameters were determined: contents of dry matter, soluble protein - albumins, globulins and prolamins, the rehydratation rate, sensory and microbial quality was assessed.

Key words: mycelium of edible boletus, quality of mycelium

\section{INTRODUCTION}

Fungi have been a source of food for humans for several thousand years. As a result of deforestation, especially at intensive mushroom harvesting, resources of wild mushrooms in natural habitats have been constantly decreasing.

In recent years, applying the advances in biochemical engineering and biotechnology, studies have been initiated on obtaining under controlled conditions of mycelia of large-fruited mushrooms, which could be used as substitutes of fruiting bodies of mushrooms in foodstuffs or as sources of active substances used in medicine (Eybergen, Scheffers 1972; Kohlmünzer 1992; Beauséjour 1999; Bilay et al. 2000; Law 2001). In this way it would be possible to limit the harvesting of mushrooms from natural habitats. Establishing conditions of mycelium culture in laboratories makes it possible to carry out studies in the field of biology, medicine and food science on all fungus species, irrespective of their seasonal occurrence (Eyb ergen, Scheffers 1972; Grzybek 1992; Kohlmünzer 1992; Hall, Wang 1998; Wasser, Weis 1999; Yang et al. 2002; Woźniak et al. 2003 a,b). Such investigations were initiated in the second half of the $20^{\text {th }}$ century in the United States by Humbfeld, where at present biomass of morel is sold as flavour substances of this mushroom species (Kopiński, Roszak 1987; Kopiński 1989; Maekawa, Intabon 2002). 
Such dried biomass for years has been competing on the American market with dried mushrooms imported from Europe (Ilczuk 1985; Ohta, Fujiwara 2003).

Production of mycelium biomass of wild mushrooms is an important issue also due to its potential application when new forests are established (Kopiński 1988; Hall, Wang 1998; Rymkiewicz 1998; Hall et al. 2003). In case of some fungi when mycelia are obtained under conditions of controlled production of submerged cultures, they may be cultivated, as it is the case e.g. with the cultivation of white truffle in New Zealand (Velling a 2003).

\section{MATERIALS AND METHODS}

The adopted objective of the study was to obtain mycelium for food production purposes from selected species of wild mushrooms characterized by large fructifications, attractive for consumers. In this study the following investigations were conducted:

1. Obtaining matrix mycelium from fruiting bodies of such mushrooms as:

Boletus edulis var. pinicola Vitt., King Bolete 'pine'

Boletus edulis var. piceicola Vasilkov, King Bolete 'spruce'

Boletus edulis var. reticulatus (Schaeff. ex Boud.) Bat, King Bolete 'reticulated'

2. Production of mycelium for food production purposes under laboratory conditions using submerged culture.

3. Physicochemical, sensory and microbial quality assessment of mycelium for food production purposes.

\section{THE CHARACTERISTIC OF EXPERIMENTAL MATERIAL}

Raw material for the production of matrix mycelium were wild mushroom fructifications growing in their natural habitats. King Bolete Boletus edulis Bull.: Fr. of three varieties were collected in the Milickie forests near Łazy Wielkie and in the Tucholskie forests near Brusy. Fruiting bodies of mushrooms, from which tissue matrix mycelium was collected, in terms of their quality and morphological characters could be classified as extra quality class according to the Polish Standard PN-76R78505 for fresh mushrooms. Fructifications were young, healthy and all the mushrooms exhibited characters characteristic of a given species and variety (Woźniak, Wąsowicz 1981). Pileus surfaces were not damp, they were properly coloured. Mushrooms had whitish hymenophores with immature spores. All the mushrooms had a typical aroma. The flesh at intersection was whitish, firm and fleshy (Grü ne rt, Grünert 1984; Laessøe, Conte 1997).

Matrix mycelium obtained from these mushrooms was used a raw material in the production of mycelium for food production purposes. The mycelium was produced and its quality was assessed in the years 1998-2004.

\section{Methods}

Mycelium production. Growth of mycelium on commercial agar solidified media.

Matrix mycelium was obtained using tissue culture from wild growing mushrooms. Reproduction of mycelium for food production purposes was produced on 
potato and wheat media. In case of experimental mycelia mycelium growth increments were established on Petri dishes. During mycelium growth the appearance of the mycelium was assessed descriptively in sensory analysis.

Mycelium proliferation using submerged liquid cultures. Proliferation was conducted in sterile liquid media, each time in 16 replications. Media were spawned with reproduction mycelium. After spawning flasks were sealed with sterile cotton wool stoppers and placed in a $358 \mathrm{~S}$ Shaker (Fig. 1). Prolification parameters were established experimentally (Woźniak 2002; Woźniak, Korzeniewska 2003). Constant $\mathrm{pH}$ and extract were maintained all that time in the medium. Growth dynamics was determined as a percentage increment of the liquid volume in reaction flasks taken up by the mycelium. The structure of mycelial filaments, the shape and colour of the mycelium were assessed visually and described every day, starting from the $2^{\text {nd }}$ day after spawning.

Tissue mycelia obtained using the traditional method were stored on Petri dishes, sterile slants and sterile wheat grain (Fig. 2). Mycelia obtained in submerged cultures after the completion of proliferation were drained on the G4 filter, thoroughly washed with water and carefully filtered and surface dried. Mycelia for food were dried in a laboratory desiccator with enforced air circulation at $35^{\circ} \mathrm{C}$ and force dried at $55^{\circ} \mathrm{C}$. The obtained dried mushrooms were packed in polyehtylene bags and next into glass jars and stored at $20-22^{\circ} \mathrm{C}$, relative humidity of $35 \%$ in the dark (Fig. 3).

Methods of quality appraisal of mycelium for food. In the biomass of mycelium for food were determined: physicochemical parameters, sensory and microbial quality was assessed.

- Determination of dry matter content using the scaling method (Charłampowicz 1966).

- Determination of contents of soluble protein compounds (in $\mathrm{H}_{2} \mathrm{O}$, in $0.1 \mathrm{M}$ $\mathrm{NaCl}$, in $15 \% \mathrm{NaOH}$ ) using the colorimetry method (Majbaum-Katzenellenbogen, Mochnacki 1968; Woźniak 1983).

- Hot determination of the rehydration coefficient in dried mycelium using the Loesecke method (Charłampowicz 1966).

- Determination of microbial purity (total microbial counts, levels of coliform bacteria, E. coli counts, contents of yeasts, moulds, the presence of coagulase-positive staphylococci) using the platelet and test methods [PN-93 A-86034/02; PN-90 A-75052/04; PN-90 A-75052/05; PN-90 A-75052/08; PN-EN-ISO 6888-2;]

- Determination of aromatic compounds using the SPME method, gas chromatography, with the identification of isolated compounds using mass spectrophotometry (Thomas 1973; Wąsowicz, Kamiński 1974).

- Sensory analyses of mycelia, using a 5-point scale according to Tilgner (Baryłko-Pikielna 1975).

- Obtained results of conducted physico-chemical and sensory analyses, as well as mycelium growth dynamics were interpreted statistically. The STAT 6 by StatSoft software was used for the calculations. To illustrate mycelium growth dynamics the equation of the constant mycelium growth was applied : $\mathrm{k}_{\mathrm{PG}}=\mathrm{r}=\partial[\varnothing] / \partial \mathrm{t}$; , in which $\mathrm{k}_{\mathrm{PG}}$ is the mycelium growth constant, $\mathrm{r}$ - function of trend, $\partial[\varnothing]$ - change in the thallus area in $\mathrm{mm}, \partial \mathrm{t}$. - change in the time of mycelium growth increment in days (Mc Ewan 1991; Brandt 2002). 


\section{RESULTS}

Mycelium for food was obtained from the second reproduction of matrix mycelium, on potato and wheat media. These media in earlier studies gave good production yields and were asessed sensorily as the best (Woźniak et al. 2000; Woźniak 2002; Woźniak et al.2002; Woźniak etal.2003a,b; Woźniak, Korzeniewska 2003; Woźniak et al. 2001; Woźniak et al. 2004; Korzeniewska, Woźniak 2005). The production of mycelium for food was completed at the moment of the phase of growth inhibition in reaction chambers.

Physico-chemical analyses were conducted immediately after production, after washing with distilled water and surface drying of mycelium. The analysis of aroma was conducted for fruiting bodies of fresh mushrooms, from which matrix mycelium was obtained. For the mycelium aroma was assessed between day 5 and day 10 of proliferation depending on the variety of the analyzed mushrooms. Sensory analyses were performed for fresh mycelium, dried mycelium and mycelium after rehydration. The appaearance (colour and consistency), taste and aroma were assessed.

For dried and ground mycelium for food the analysis of microbial purity was conducted in the range of analyses required for dried mushrooms.

The production of mycelium for food was completed at the moment of the phase of growth inhibition in reaction chambers. Mycelia of all varieties grew faster on potato medium. Proliferation of matrix mycelium lasted approx. 64 days for the "spruce" variety, 74 days for the "pine" variety and 76 days for the "reticulated" variety. The production of biomass in case of mycelium for food lasted much shorter and thus it was 12 days for "pine" variety on potato medium and 14 days on wheat medium, for the "reticulated" variety it was 8 days on potato medium and 10 days on wheat medium. Mycelium, irrespective of the medium type, grew unformly in the form of hyphae, which constituted branching threads (Tabs 1-2, Figs 4-9).

Mycelia of King Bolete in comparison to fruiting bodies had comparable contents of dry matter. Depending on the medium used for proliferation, in mycelia obtained from potato and wheat media the solids content for King Bolete ranged

Table 1

Constant $\mathrm{k}_{\mathrm{PG}}$ for growth changes in matrix mycelium

\begin{tabular}{|c|c|c|c|}
\hline \multirow{2}{*}{ Medium } & \multicolumn{3}{|c|}{ Constant $\mathrm{k}_{\mathrm{PG}}$ for King Boletus } \\
\cline { 2 - 4 } & 'spruce' & 'pine' & 'reticulated' \\
\hline wheat & 1.86 & 1.16 & 1.81 \\
\hline potato & 2.14 & 1.54 & 1.93 \\
\hline
\end{tabular}

Table 2

Constant $\mathrm{k}_{\mathrm{PG}}$ for growth cymelium in submerged liquid method

\begin{tabular}{|c|c|c|c|}
\hline \multirow{2}{*}{ Medium } & \multicolumn{3}{|c|}{ Variety of King Boletus } \\
\cline { 2 - 4 } & 'spruce' & 'pine' & 'reticulated' \\
\hline wheat & 7.40 & 14.63 & 8.54 \\
\hline potato & 9.29 & 18.06 & 9.71 \\
\hline
\end{tabular}




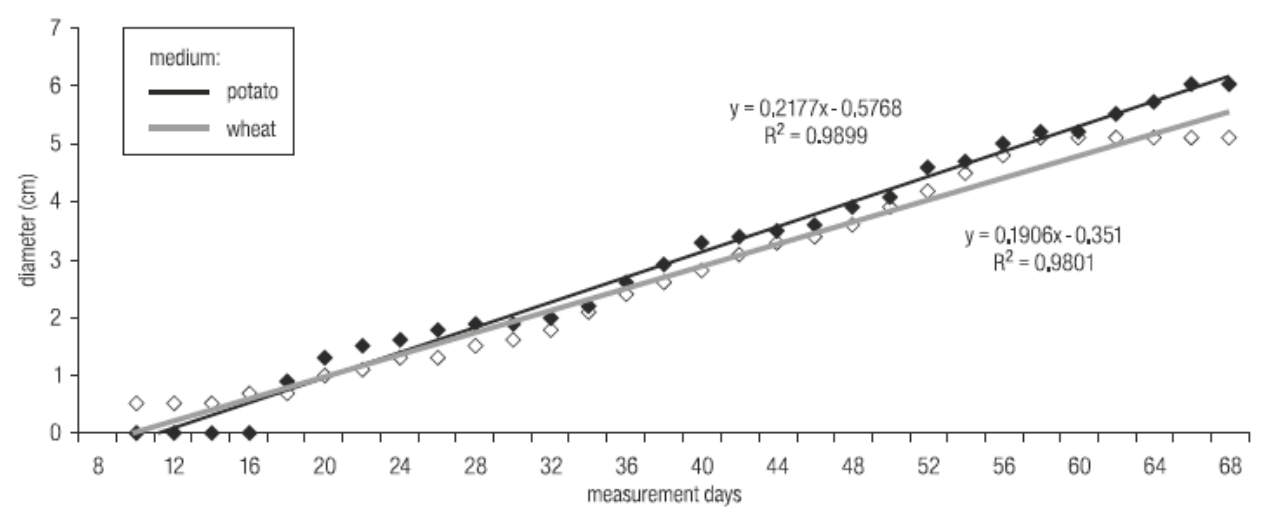

Fig. 4. Growth dynamic of matrix mycelium of 'pine' King Boletus.

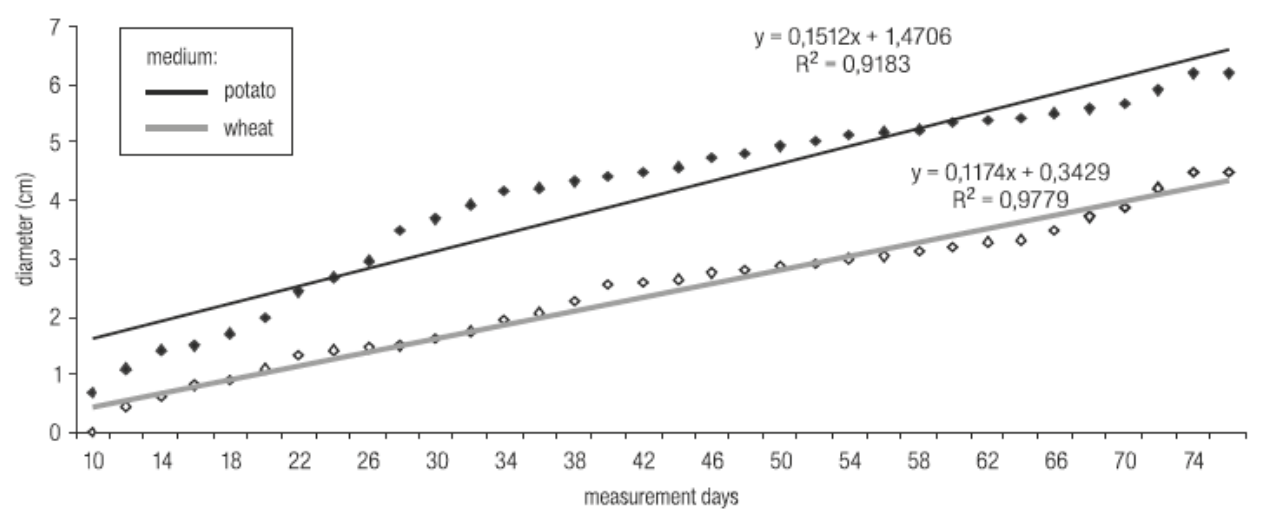

Fig. 5. Growth dynamic of matrix mycelium of 'spruce' King Boletus.

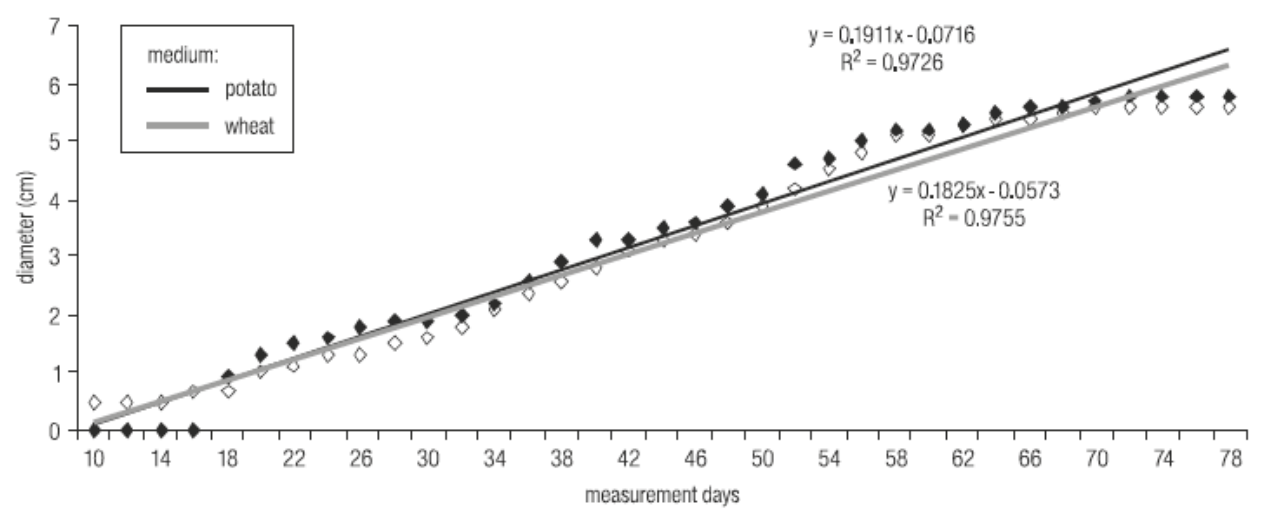

Fig. 6. Growth dynamic of matrix mycelium of 'reticulated' King Boletus.

from $8.07 \%$ to $9.77 \%$ (Tabs 3-5). Mycelia of 'spruce' and 'reticulated' proliferated on potato medium in comparison to wheat medium contained less dry matter. The trend was opposite in case of mycelium of 'pine' King Bolete. 


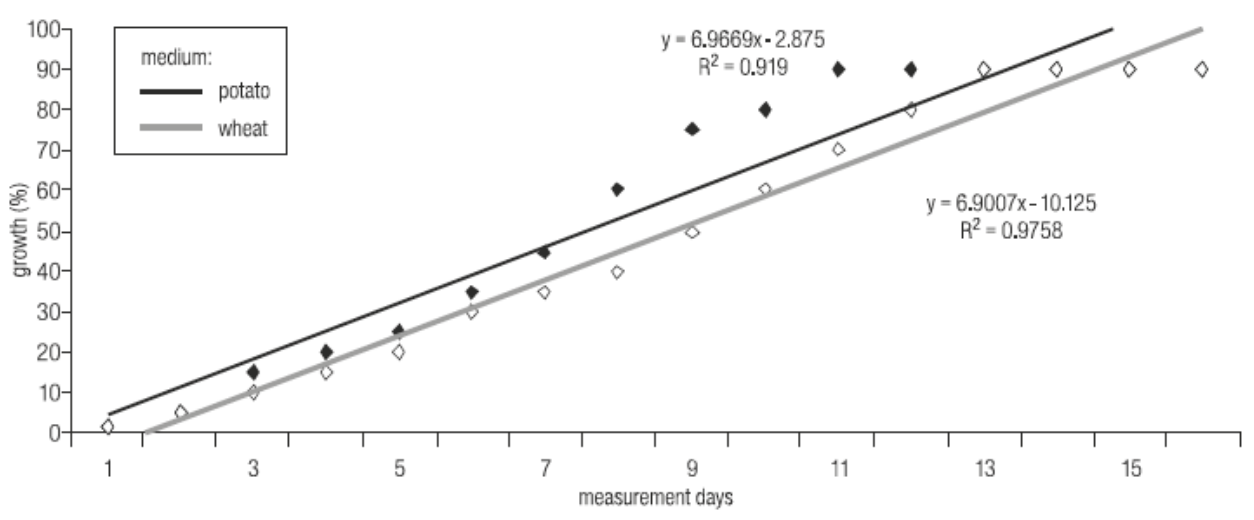

Fig. 7. Growth dynamics of biomass mycelium of 'pine' King Boletus.

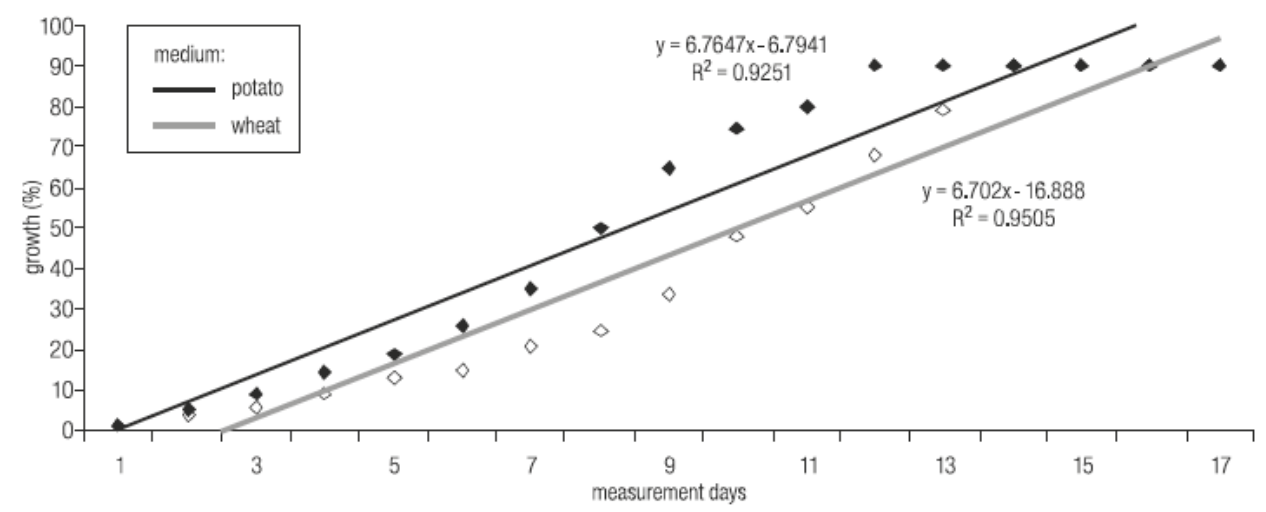

Fig. 8. Growth dynamics of biomass mycelium of 'spruce' King Boletus.

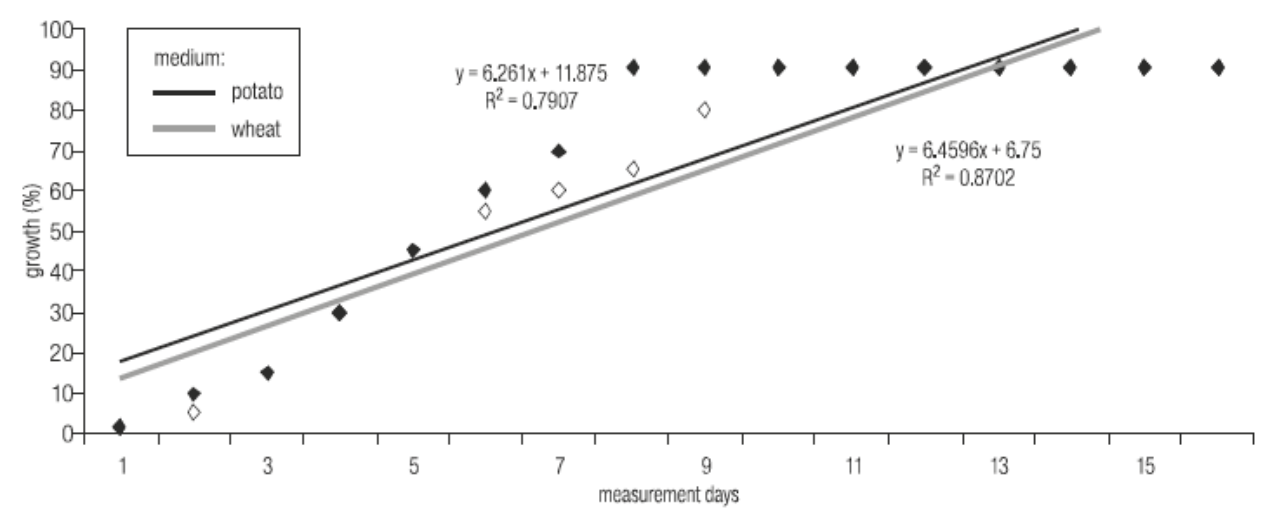

Fig. 9. Growth dynamics of biomass mycelium of 'reticulated' King Boletus.

Total contents of soluble proteins ranged from $30.08 \mathrm{~g} / 100 \mathrm{~g}$ d.s. for mycelium of reticulated King Bolete obtained on wheat medium to $33.49 \mathrm{~g} / 100 \mathrm{~g}$ d.s. for mycelium of 'spruce' King Bolete cultured on potato medium. Contents of individual protein 
Table 3

Contents of selected chemical contents in mycelium of 'spruce' King Boletus

\begin{tabular}{|c|c|c|c|c|}
\hline \multirow[t]{2}{*}{ Analysis } & \multicolumn{4}{|c|}{ Contents } \\
\hline & $\begin{array}{c}\text { mean } \\
(n=16)\end{array}$ & minimum & maximum & $\begin{array}{c}\text { coefficient of } \\
\text { variation }\end{array}$ \\
\hline \multicolumn{5}{|c|}{ multiplying on potato medium } \\
\hline Dry matter (\%) & 8.53 & 8.42 & 8.62 & 1.17 \\
\hline $\begin{array}{l}\text { (g/100g s.s.) } \\
\text { total solube } \\
\text { protein } \\
\text { albumins } \\
\text { globulins } \\
\text { prolamins }\end{array}$ & $\begin{array}{r}33.49 \\
18.94 \\
11.39 \\
3.16\end{array}$ & $\begin{array}{c}33.65 \\
18.74 \\
11.25 \\
2.98\end{array}$ & $\begin{array}{r}33.31 \\
19.08 \\
11.59 \\
3.32 \\
\end{array}$ & 1.15 \\
\hline \multicolumn{5}{|c|}{ multiplying on wheat medium } \\
\hline Dry matter (\%) & 9.14 & 9.04 & 9.22 & 0.76 \\
\hline $\begin{array}{l}\text { (g/100g s.s.) } \\
\text { total solube } \\
\text { protein } \\
\text { albumins } \\
\text { globulins } \\
\text { prolamins }\end{array}$ & $\begin{array}{r}32.71 \\
18.58 \\
11.41 \\
2.72 \\
\end{array}$ & $\begin{array}{c}32.57 \\
18.45 \\
11.26 \\
2.60\end{array}$ & $\begin{array}{c}32.85 \\
18.71 \\
11.52 \\
2.86\end{array}$ & 1.67 \\
\hline
\end{tabular}

$\mathrm{n}=$ number of samples collected for analyses

Table 4

Contents of selected chemical contents in mycelium of 'pine' King Boletus

\begin{tabular}{|c|c|c|c|c|}
\hline \multirow[t]{2}{*}{ Analysis } & \multicolumn{4}{|c|}{ Contents } \\
\hline & $\begin{array}{c}\text { mean } \\
(\mathrm{n}=16)\end{array}$ & minimum & maximum & $\begin{array}{c}\text { coefficient of } \\
\text { variation }\end{array}$ \\
\hline \multicolumn{5}{|c|}{ multiplying on potato medium } \\
\hline Dry matter $(\%)$ & 8.25 & 8.10 & 8.32 & 1.21 \\
\hline $\begin{array}{l}\text { (g/100g s.s.) } \\
\text { total solube } \\
\text { protein } \\
\text { albumins } \\
\text { globulins } \\
\text { prolamins }\end{array}$ & $\begin{array}{c}32.84 \\
17.89 \\
11.47 \\
3.48\end{array}$ & $\begin{array}{c}32.75 \\
17.78 \\
11.42 \\
3.41\end{array}$ & $\begin{array}{c}32.89 \\
17.92 \\
11.56 \\
3.55\end{array}$ & 0.74 \\
\hline \multicolumn{5}{|c|}{ multiplying on wheat medium } \\
\hline Dry matter $(\%)$ & 8.07 & 8.01 & 8.13 & 0.38 \\
\hline $\begin{array}{c}\text { (g/100g s.s.): } \\
\text { total solube } \\
\text { protein } \\
\text { albumins } \\
\text { globulins } \\
\text { prolamins }\end{array}$ & $\begin{array}{r}31.53 \\
16.30 \\
10.88 \\
4.35 \\
\end{array}$ & $\begin{array}{r}31.13 \\
16.09 \\
10.79 \\
4.25 \\
\end{array}$ & $\begin{array}{r}31.79 \\
16.31 \\
11.01 \\
4.47 \\
\end{array}$ & 1.21 \\
\hline
\end{tabular}

$\mathrm{n}=$ number of samples collected for analyses

fractions for mycelia of the same variety differed depending on the medium used for proliferation. In mycelia grown on potato medium the content of soluble protein was slightly higher than in mycelia obtained from wheat medium. The differences amounted to $2.4 \%$ for 'spruce' King Bolete, $2.8 \%$ for 'pine' King Bolete and $4.3 \%$ for 'reticulated' King Bolete. Contents of albumins ranged from $52 \%$ to $63 \%$ soluble protein contents, while those of globulins from $22.7 \%$ to $36 \%$ and prolamins from $8.3 \%$ to $15.6 \%$, respectively (Tabs $3-5$ ).

The hot determination of the rehydration ratio was conducted for 20 minut. The coefficient was high and amounted to approx. 6 for 'spruce' and 'pine' King Bo- 
Table 5

Contents of selected chemical contents in mycelium of 'reticulated' King Boletus

\begin{tabular}{|c|c|c|c|c|}
\hline \multirow[t]{2}{*}{ Analysis } & \multicolumn{4}{|c|}{ Contents } \\
\hline & $\begin{array}{c}\text { mean } \\
(\mathrm{n}=16)\end{array}$ & minimum & maximum & $\begin{array}{l}\text { coefficient of } \\
\text { variation }\end{array}$ \\
\hline \multicolumn{5}{|c|}{ multiplying on potato medium } \\
\hline Dry matter $(\%)$ & 8.44 & 8.40 & 8.46 & 0.27 \\
\hline $\begin{array}{l}\text { (g/100g s.s.) } \\
\text { total solube } \\
\text { protein } \\
\text { albumins } \\
\text { globulins } \\
\text { prolamins }\end{array}$ & $\begin{array}{r}30.94 \\
17.19 \\
10.41 \\
3.34 \\
\end{array}$ & $\begin{array}{r}30.75 \\
16.96 \\
10.23 \\
3.14 \\
\end{array}$ & $\begin{array}{r}31.13 \\
17.36 \\
10.63 \\
3.54 \\
\end{array}$ & 1.11 \\
\hline \multicolumn{5}{|c|}{ multiplying on wheat medium } \\
\hline Dry matter $(\%)$ & 9.77 & 9.69 & 9.85 & 0.73 \\
\hline $\begin{array}{c}\text { (g/100g s.s.): } \\
\text { total solube } \\
\text { protein } \\
\text { albumins } \\
\text { globulins } \\
\text { prolamins }\end{array}$ & $\begin{array}{r}30.08 \\
15.85 \\
10.89 \\
3.34\end{array}$ & $\begin{array}{c}29.94 \\
15.68 \\
10.76 \\
3.22\end{array}$ & $\begin{array}{r}30.22 \\
15.96 \\
11.04 \\
3.55\end{array}$ & 1.21 \\
\hline
\end{tabular}

$\mathrm{n}=$ number of samples collected for analyses

lete and approx. 5.5 for 'reticulated' King Bolete. Rehydration time for 'spruce' and 'pine' King Bolete was 5 minutes, whereas for mycelium of 'reticulated' King Bolete - 15 minutes (Figs 10-11).

Mycelia in the powdered form were not objectionable in terms of microbial purity. No E. coli, Staphylococcus or mould spores were found and yeast count was 20 times lower than the admissible limit for dried mushrooms in the Polish Standard (Tab. 6).

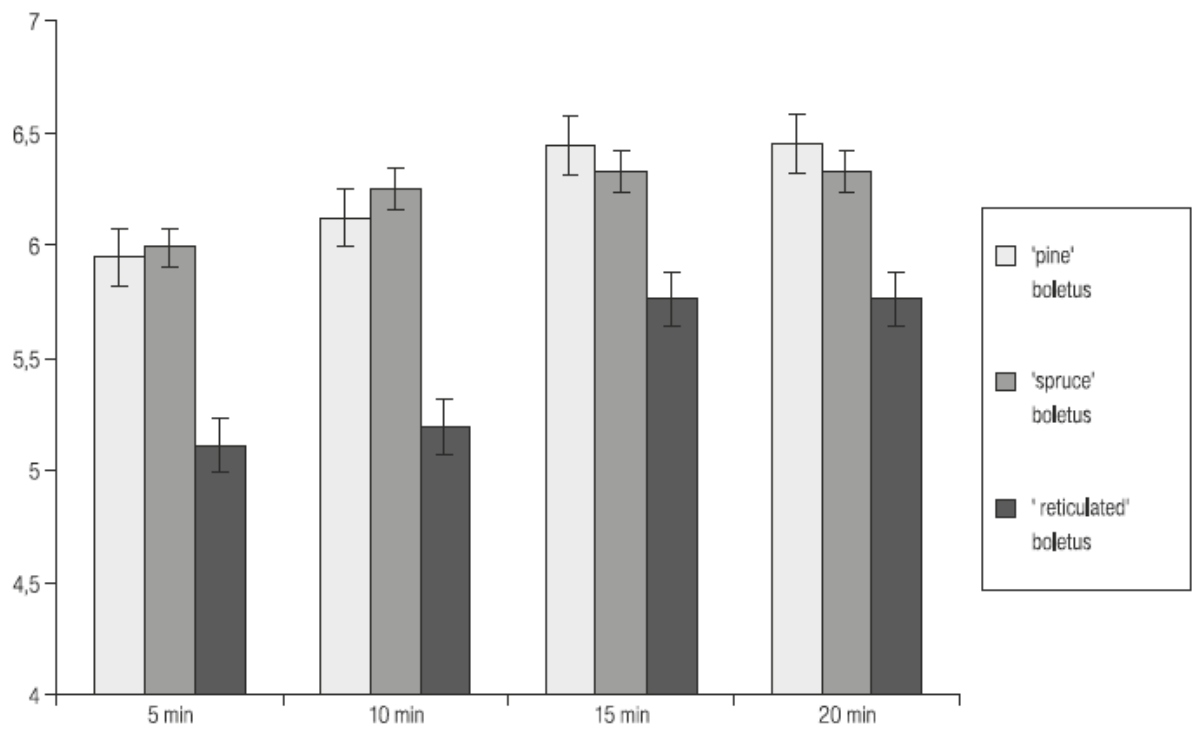

Fig. 10. Coefficient of rehydratation factor for dried mycelium grown on potato medium. 


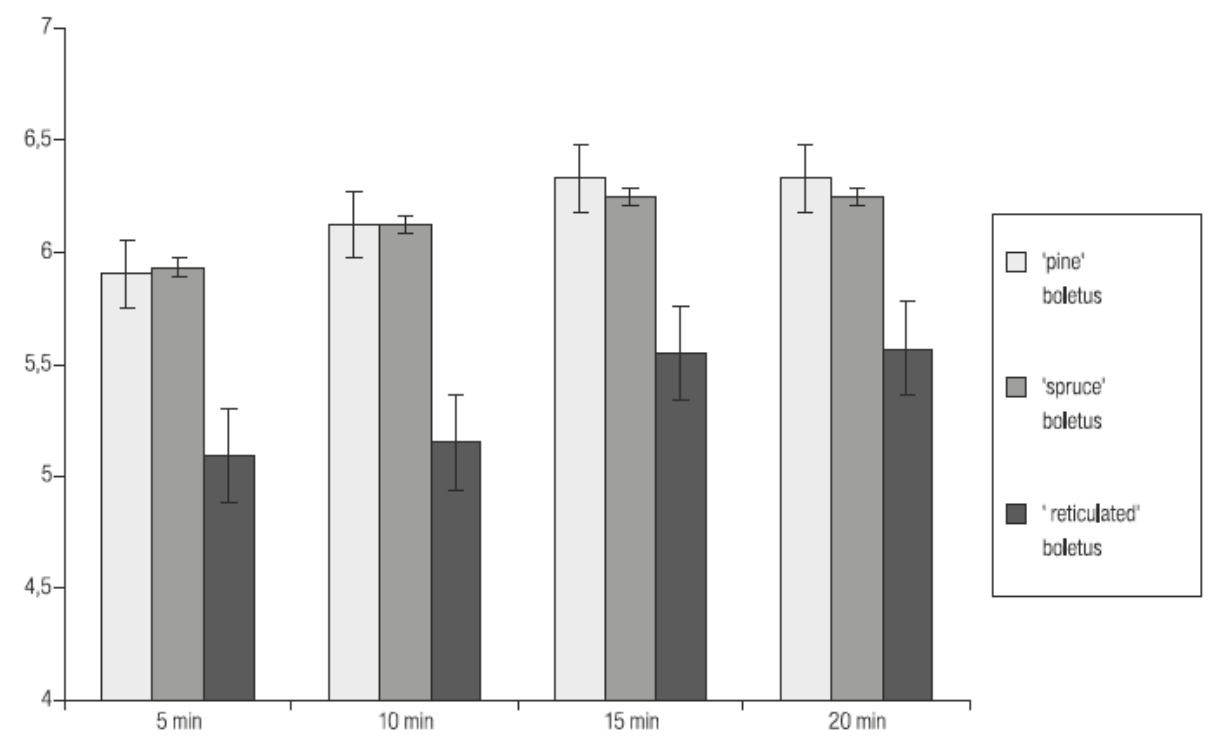

Fig. 11. Coefficient of rehydratation factor for dried mycelium grown on wheat medium.

In terms of sensory analysis all mycelia, both fresh and dried, received high notes (Figs 12-17). Mycelia obtained from wheat medium were lighter in colour from mycelium grown on potato medium. In turn, the score for taste and aroma was slightly lower (Tabs 7-8). The taste of all mycelia was mushroom, more intensive for mycelium from potato medium. Aroma was also more typical and much more intensive for mycelium from potato medium (Tab. 7). Minimal changes were found in the quality of colouring of dried mycelium after cooking. Under the influence of cooking of mycelium the intensity of taste and aroma and their typicality increased in comparison to non-rehydrated mycelium (Figs 14-15) and for rehydration mycelium (Figs 16-17).

Volatile compound scontained in mycelium were determined using chromatography and identified using spectrophotometry ranged from $40 \%$ for 'spruce' King Bolete to approx. $18 \%$ for 'reticulated' King Bolete in comparison to mushroom fruiting bodies. The octacarbon compounds constituted from 73 to $88 \%$ isolated volatile compounds. The primary compound with the mushroom aroma (1-octene-3-ol)

Table 6

Contents of microbiological contamination in $\mathrm{kg}$ dried mycelium $(\mathrm{n}=5)$

\begin{tabular}{|c|c|c|c|}
\hline \multirow{2}{*}{ Analysis } & \multicolumn{2}{|c|}{ Mycelium of King Bolete - varietes } \\
\cline { 2 - 4 } & 'spruce' & 'pine' & 'reticulated' \\
\hline Total microbiological conts & 2.800 & 3.700 & 4.500 \\
\hline Total coliform bacteria & 200 & 300 & 100 \\
\hline E. coli bacteria & not found & not found & not found \\
\hline Staphylococcus & not found & not found & not found \\
\hline Yeast & $<100$ & $<100$ & $<100$ \\
\hline Moulds & not found & not found & not found \\
\hline
\end{tabular}

$\mathrm{n}=$ number of samples collected for analyses 
Table 7

Description of biomass for food of King Bolete

\begin{tabular}{|c|c|c|c|c|}
\hline \multirow{2}{*}{ Varietas } & \multirow{2}{*}{ Medium } & \multicolumn{3}{|c|}{ Quality attributes } \\
\cline { 2 - 5 } & & colour & taste & aroma \\
\hline \multirow{2}{*}{ 'spruce' } & potato & light-cream & mushroom & $\begin{array}{c}\text { mushroom } \\
\text { intensive }\end{array}$ \\
\cline { 2 - 5 } & wheat & light-cream-white & mushroom & $\begin{array}{c}\text { mushroom, } \\
\text { average intensive }\end{array}$ \\
\hline \multirow{2}{*}{ 'pine' } & potato & light-cream & mushroom & $\begin{array}{c}\text { mushroom } \\
\text { intensive }\end{array}$ \\
\cline { 2 - 5 } & wheat & light -cream-white & small mushroom & small mushroom \\
\hline \multirow{2}{*}{ 'reticulated' } & potato & cream & mushroom & mushroom \\
\cline { 2 - 5 } & wheat & cream-beige & small mushroom & small mushroom \\
\hline
\end{tabular}

Table 8

Aroma components in mycelium and fruting bodies

\begin{tabular}{|c|c|c|c|c|}
\hline \multicolumn{5}{|c|}{ Contents of aroma components in ppm } \\
\hline \multirow{2}{*}{ King Bolete } & $\begin{array}{c}\text { volatile } \\
\text { componends }\end{array}$ & $\begin{array}{c}\text { 8-carbon } \\
\text { compounds }\end{array}$ & 1-octen-3-ol \\
\hline \multirow{2}{*}{ 'spruce' } & fruting $^{1}$ & 6484 & 6329 & 6293 \\
\cline { 2 - 5 } & mycelium $^{2}$ & 2830 & 2488 & 725 \\
\hline \multirow{2}{*}{ 'pine' } & fruting $^{1}$ & 11496 & 10974 & 10816 \\
\cline { 2 - 5 } & mycelium $^{2}$ & 2235 & 1600 & 642 \\
\hline \multirow{2}{*}{ 'reticulated' } & fruting $^{1}$ & 20584 & 15375 & 222 \\
\cline { 2 - 5 } & mycelium $^{2}$ & 3662 & 2820 & 1052 \\
\hline
\end{tabular}

Explanations: ${ }^{1}$ Aroma components of fresh fruting bodies analyzed for mushrooms from which matrix mycelium was obtained.

${ }^{2}$ Aroma components of mycelium biomass obtained in submerged liquid cultures on potato medium on day 5 of proliferation.

amounted in the fruiting body of 'spruce' and 'pine' King Bolete approx. $99 \%$ and in the 'reticulated' variety $72 \%$ total volatile compounds. In mycelia of these species it was $40 \%$ for 'pine" King Bolete, $29 \%$ for 'spruce' variety and $8 \%$ for 'reticulated" variety, respectively (Tab. 8).

\section{CONCLUSIONS}

Problems investigated in this study concern the production of high quality mycelium of King Bolete of three varieties: 'pine', 'spruce' and 'reticulated'.

In the conducted investigations it was found that:

1. Composition of the medium applied for proliferation has a significant effect on growth dynamics of mycelium and on its quality.

2. Physico-chemical indexes (protein contents and dry matter, aromatic volatile substances), sensory attributes (appearance, taste and aroma) and microbial indexes indicate high quality of the produced mycelia.

3. Mycelia produced from the analyzed mushroom varieties after drying may constitute a good supplement of dried mushroom in foodstuffs. 


\section{REFERENCES}

B aryłk o-Pikieln a N. 1975. Zarys analizy sensorycznej żywności. WNT, Warszawa.

Beau séjour T. M. 1999b. Getting Started with Mushroom Cultivation. www.mycoweb.com/articels/ cultivation.html.

Bilay V. T., Solomko E. F., Buchalo A. S. 2000. Growth of edible and medicinal mushrooms on commercial agar media. Science and Cultivation of Edible Fungi. Van Griensven (ed.). Balkema, Rotterdam: 779-782.

Brandt S. 2002. Analiza danych. Metody statystyczne i obliczeniowe. PWN, Warszawa.

Ch arła mpowicz Z. 1966. Analizy przetworów z owoców, warzyw i grzybów. WPLiS. Warszawa: 133-135.

Eybergen G.C. van, Scheffers W.A. 1972. Growth of the mycelium of Boletus edulis on agar media and in submerged liquid cultures. Antonie van Leeuwenhoek; J. Microbiol. Serol. 38: 448-450.

Grủnert H., Grűnert R. 1984. Pilze. Mosaik Verlag GmbH, Monachium: 52-56: 118.

Gr zy be k J. 1992. Kultury mycelialne grzybów wyższych źródłem substancji leczniczych. Biotech. 4 (19): $37-40$.

Hall I. R., Wang Y. 1998. Methods for cultivating edible ectomycorrhizal mushrooms. Mycorrhiza manual. A. Varma (ed.). Springer Laboratory Manual. Springer Verlag, Heidelberg: 99-114.

Hall I. R., Yun W., Amicucci A. 2003. Cultivation of edible ectomycorrhizal mushrooms. Trends in Biotech. 21 (10): 433-438.

Ilczuk Z. 1985. Wgłębna hodowla grzybów jadalnych. Grzyby 12: 30.

Kohlmünzer S. 1992. Hodowle myceliarne grzybów wyższych jako źródło biologicznie aktywnych substancji. Probl. Hig. 36: 10-15.

Kopiński L., Roszak J. 1987. Badanie zmian morfologii cząstek grzybni podczas hodowli wgłębnej. Przem. Ferm. i Owoc.-Warz. 9: 3-5.

Kopiński L. 1988. Wgłębna hodowla grzybni pieczarki (Agaricus bisporus), boczniaka ostrygowatego (Pleurotus ostreatus) w podłożach zawierających odpady rolno-spożywcze. Przem. Ferm. i Owoc.Warz. 5: 21-24.

Kopiński L. 1989. Poprawa właściwości aromatyzująco-smakowych grzybni boczniaka i twardzika rosnących w płynnych podłożach odpadowych. Przem. Ferm. i Owoc.-Warz. 1: 17-18.

Korzeniewska A., Woźniak W. 2005. Produkcja i ocena biomasy grzybni czubajki kani Macrolepiota procera (Scop. ex Fr.) Sing. Materiały Konferencji Naukowej „Żywienie a zdrowie - interakcje”. 9-10 czerwca 2005, Kraków: 56.

Laessøe T., Conte A. 1997. Grzyby. Wielka Księga. Wiedza i Życie, Warszawa.

Law D. 2001. Fungi as a Platform for New Medicine. Mushrooms, Fungi and Medicine: www.gmushrooms.com

Maekawa T., Intabon K. 2002. United States Patent 6, 490, 824. Method for culturing a basidiomycetous fungus in a liquid culture medium.

Majbaum-Katzenellenbogen W., Mochnacki I. 1968. Kurs praktyczny z biochemii. PWN, Warszawa.

McEwan J. 1991. Statistical analysis of sensory data. Mat. Międzynar. Konf. Naukowej nt Analiza sensoryczna żywności - metody i zastosowania. Mądralin k/Otwocka: 319-320.

Ohta A., Fujiwara N. 2003. Fruit-body production of an ectomycorrhizal fungus in genus Boletus in pure culture. Mycoscience 44: 295-300.

Rymkiewicz A. 1998. Hodowla grzybów kapeluszowych in vitro. Biul. Pieczarki 4: 49-54.

Th om as A. F. 1973. Analysis of the Flavour of the Dried Mushroom, Boletus edulis. J. Agricult. Food Chem. 21 (6): 955-958.

Velling a E. C. 2003. Chlorophyllum and Macrolepiota (Agaricaceae) in Australia. Australian Systematic Botany 16: 361-370.

Wasser S. P., We is A. L. 1999. Therapeutic effects of substances occurring in higher Basidiomycetes mushrooms: a modern perspective. Crit. Rev. Immunol. 19: 65-96.

Wąs owicz E., Kamiński E. 1974. Substancje zapachowe borowika szlachetnego (Boletus edulis). Przem. Spoż. 6: 269-270.

Woźniak W., Wąsowicz E. 1981. Volatile flavour components of mushrooms: Boletus edulis, Xerocomus badius and Tricholoma equestre. Int. Symp. Flavour Research Concepts and Method. Rydzyna.

Woźniak W. 1983. Azotowe składniki pokarmowe grzybów. Grzyby 3: 19-22. 
Woźniak W., Gapiński M., Muras U., Korzeniewska A. 2000. Ocena biomasy grzybni shiitake odmiany $37 * 37$ z hodowli wgłębnej. Roczniki AR w Poznaniu, CCCXXIII. Ogrodnictwo 31 (1): 561-565.

Woźniak W., Muras U., Korzeniewska A., Gapiński M. 2001. Growth of Agaricus bisporus (Lange) Sing. mycelium as influenced by production method. Vegetable Crops Res. Bull., Poland-Skierniewice 54 (2): 83-86.

Woźn ia k W. 2002. Raport z badań nad produkcją grzybni wielkoowocnikowych grzybów w latach 19972002. Materiały niepublikowane, do wglądu w ITŻPR AR w Poznaniu.

Woźniak W., Muras U., Korzeniewska A., Gapiński M. 2002. Opracowanie warunków produkcji grzybni pieczarki dwuzarodnikowej odmiany Polmycel 3201 metodą wgłębną. Materiały XXXIII Sesji Naukowej KTiChŻ PAN „Nauka o Żywność. Osiągnięcia i Perspektywy”. 10-11 wrzesień 2002, Lublin: 270.

Woźniak W., Gapiński M., Muras U., Korzeniewska A. 2003a. Ocena jakości grzybni shiitake odmiany SH 21 wyprodukowanej metodą wgłębną. Materiały II Krajowego Kongresu Biotechnologii, 23-27 czerwiec 2003, Łódź: 21.

Woźniak W., Gapiński M., Korzeniewska A., Muras U. 2003b. Wzrost i charakterystyka biomasy grzybni soplówki. Folia Horti., 1: 142-145.

Woźniak W., Korzeniewska A. 2003. Produkcja biomasy i ocena grzybni borowika szlachetnego. Folia Horti. 1: 349-351.

Woźniak W., Muras U., Korzeniewska A. 2004. Wpływ przechowywania grzybni borowika szlachetnego Boletus edulis (Fries) na jej żywotność. Folia Univ. Agric. Stetin., Agricultura 95: 425-429.

Yang J. H., Lin H. Ch., Mau J. L. 2002. Antioxidant properties of several commercial mushrooms. Food Chem. 77: 229-235.

PN-76 R-78505 - Grzyby świeże.

PN-93 A-86034/02 - Badania mikrobiologiczne - ogólne zasady badań.

PN-90 A-75052/04 - Metody badań mikrobiologicznych. Sposób pobierania i przygotowanie próbek do badań mikrobiologicznych.

PN-90 A-75052/05 - Metody badań mikrobiologicznych. Oznaczanie obecności i liczby drobnoustrojów tlenowych mezofilnych i psychrofilnych.

PN-90 A-75052/08 - Metody badań mikrobiologicznych. Oznaczanie liczby drożdży i pleśni.

PN-EN-ISO 6888-2-Mikrobiologia żywności i pasz-Horyzontalna metoda oznaczania liczby gronkowców koagulazo-dodatnich (Staphylococcus aureus i innych gatunków)

\section{Charakterystyka biomasy grzybni borowika szlachetnego}

\section{Streszczenie}

Wykorzystując osiągnięcia inżynierii biochemicznej i biotechnologii, rozpoczęto w ostatnich latach badania nad otrzymaniem grzybni grzybów wielkoowocnikowych w warunkach kontrolowanych, którą można byłoby wykorzystać jako zamienniki owocników grzybów w produktach spożywczych. W ten sposób ograniczyć można byłoby zbiór grzybów ze środowisk naturalnych dla przetwórstwa. Publikacja przedstawia wyniki badań nad oceną grzybni dla celów spożywczych z wybranych odmian atrakcyjnego gatunku Boletus edulis. W tym opracowaniu przedstawiono badania dotyczące otrzymania grzybni matecznej i spożywczej owocników następujących grzybów: borowik szlachetny 'sosnowy' Boletus edulis var. pinicolus Vitt., borowik szlachetny 'świerkowy' Boletus edulis var. piceicolus Vasilkov, borowik szlachetny 'usiatkowany' Boletus edulis var. reticulatus (Schaff ex. Boud) Bat. Grzybnię wyprodukowano w warunkach laboratoryjnych metodą wgłębną na wytrząsarce Shaker typ 358S, na pożywce pszennej i ziemniaczanej. Ocena jakości grzybni obejmowała współczynniki: fizykochemiczne, sensoryczne oraz mikrobiologiczne. W przeprowadzonych badaniach stwierdzono, że pozyskiwane grzybnie były wysokiej jakości. Wyróżniki fizykochemiczne: zawartość białka i sucha substancja oraz substancje lotne aromatu; sensoryczne: wygląd, smak i zapach oraz mikrobiologiczne, wskazują na wysoką jakość otrzymywanych grzybni. Skład fizykochemiczny grzybni zależał w sposób istotny od odmiany borowika i zastosowanej pożywki. 


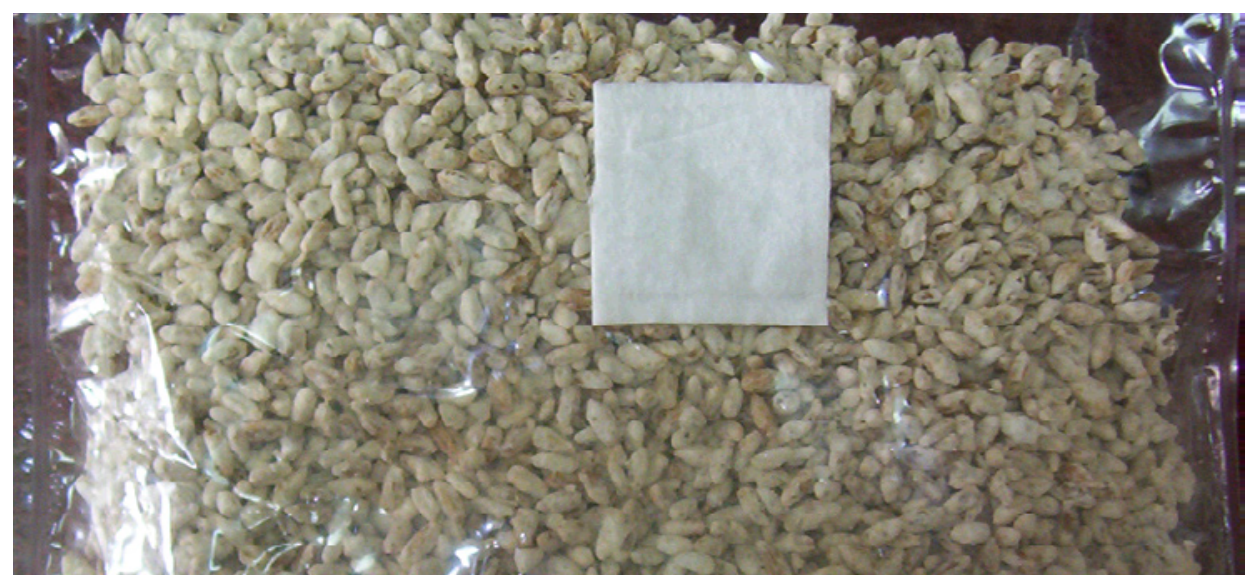

Fig. 1. Biomass of matrix mycelium transmitted on grain.

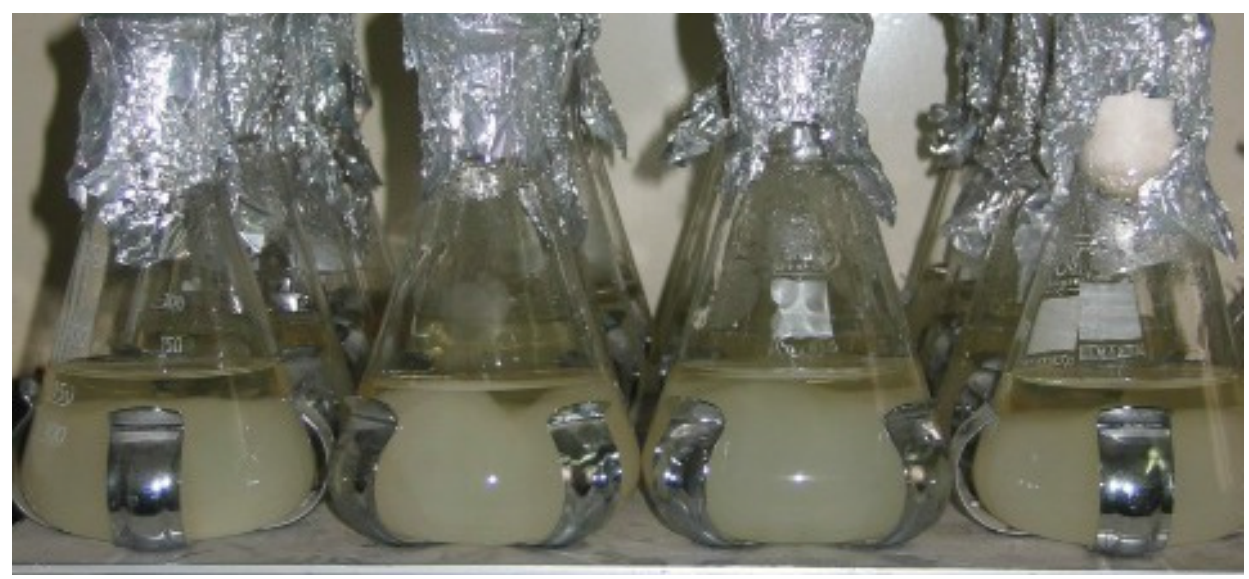

Fig. 2. Mycelium of Boletus obtained in submerged liquid culture.

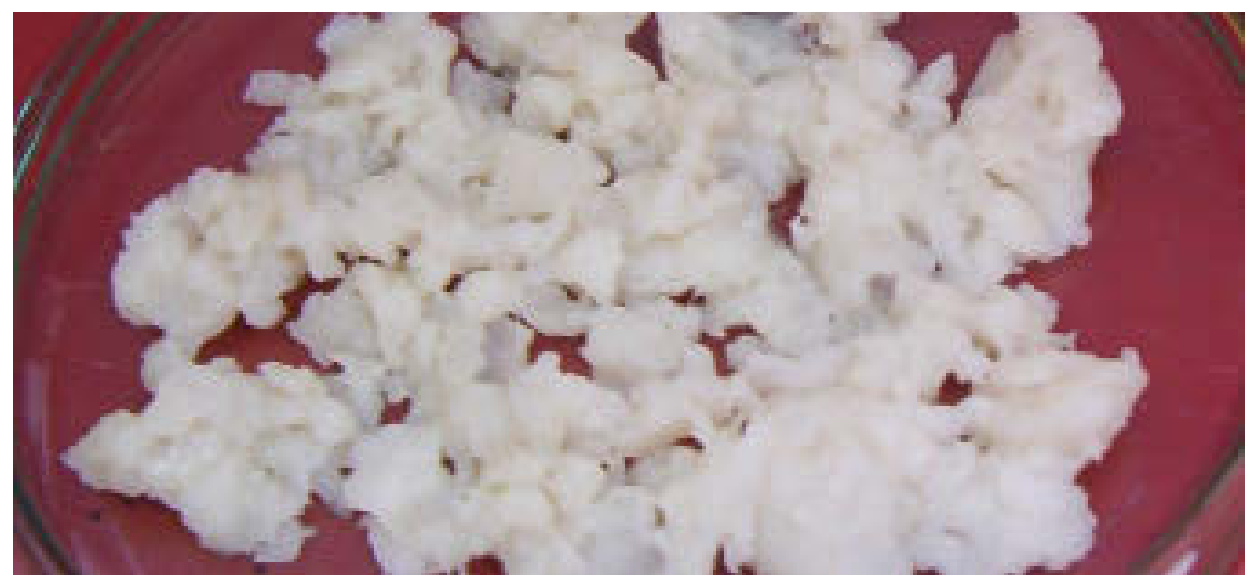

Fig. 3. Dried biomass of mycelium for food. 


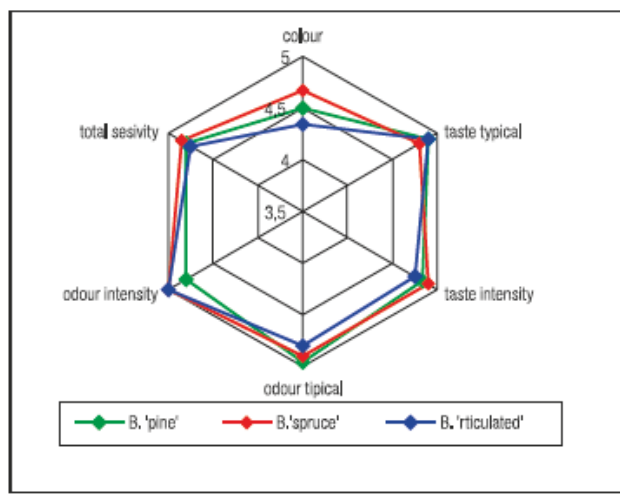

Fig. 12. Sensory assessment for fresh mycelium of Boletus edulis in potato medium.

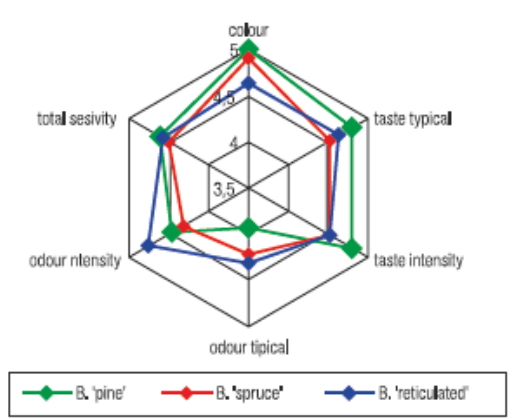

Fig. 13. Sensory assessment for fresh mycelium of Boletus edulis in wheat medium.

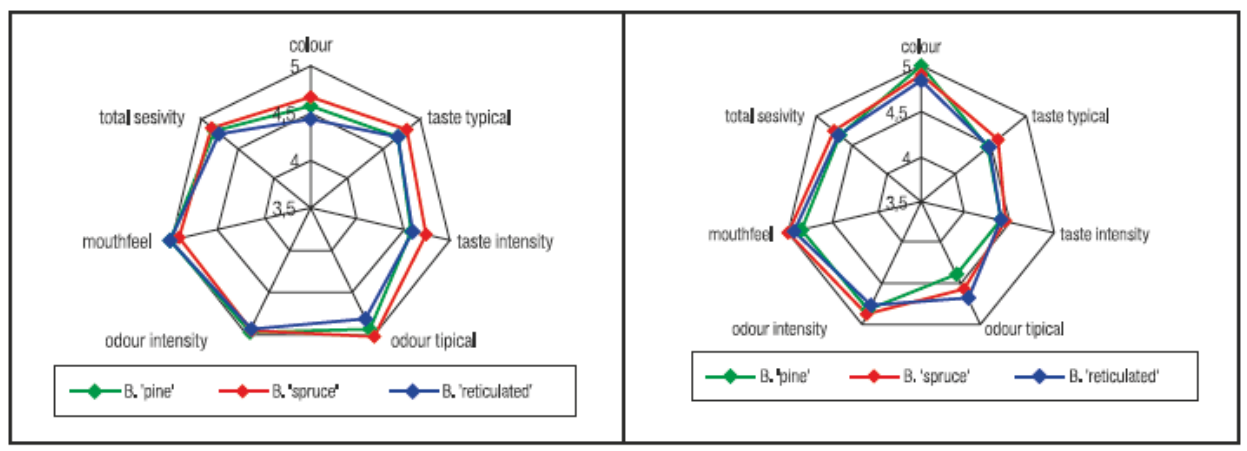

Fig. 14. Sensory assessment for dried mycelium of Boletus edulis in potato medium.
Fig. 15.Sensory assessment for dried mycelium of Boletus edulis in wheat medium.

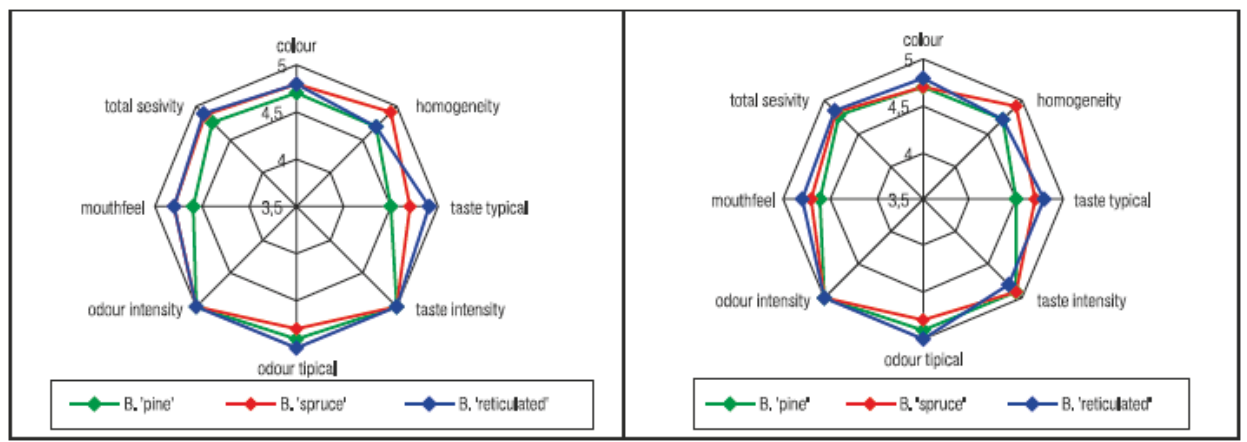

Fig. 16. Sensory assessment for rehydratation dried mycelium of Boletus edulis in potato medium.
Fig. 17. Sensory assessment for rehydratation dried mycelium of Boletus edulis in wheat medium. 